\title{
Local Wisdom Of Kampung Naga In The Era Of Globalization
}

\author{
Hanny Harashani ${ }^{*}$ \\ ${ }^{*}$ Universitas Pakuan, Bogor, Indonesia \\ Corresponding Author: liefantje53@gmail.com
}

\begin{abstract}
This study aims to describe the local wisdom of Kampung Naga which is located in Tasikmalaya, West Java, is a village inhabited by a group of people who are very strong in holding the traditions of their ancestors, namely Sundanese customs. As part of the Sundanese people, Kampung Naga residents have enriched Sundanese culture that has wisdom in the local knowledge system to maintain the rituals of their lives, as a harmonization of human, natural and environmental relations. They have livelihoods besides farming, which is making crafts with bamboo raw materials. Both of these activities become the family's economic backbone to fulfill their daily needs. This society is not a primitive society or an isolated tribe, instead they are a society that has followed a modern lifestyle, but they still maintain their customs and traditions, have a mindset that is far ahead, because they are rich in philosophical teachings and values that sublime and obedient to the norms, socio-cultural values resulting from the decisions of the adat and religious deliberations in Islam. The above ceremonies are still preserved by the Kampung Naga community as indigenous communities that are full of various traditions and can be applied in their daily lives, making Kampung Naga a tourist attraction in West Java, especially for domestic tourists. and foreign countries, which ultimately affect their socio-economic fields.
\end{abstract}

Keywords: local wisdom, globalization era, Kampung naga.

\section{INTRODUCTION}

Kampung Naga is a collection of one of the indigenous peoples in West Java who still retain cultural values and traditions of their ancestral heritage, and have a distinctive identity from the community. The location of Kampung Naga is culturally located among the hills in the Salawu area across the southern route area of Garut-Tasikmalaya, or more precisely in the Neglasari village, Salawu sub-district, Tasikmalaya district, West Java province bordering the Ciwulan river to the north and east, then to the west and south bordering the hills. The road to Kampung Naga is quite steep, we have to go down 340 stairs, and the uniqueness of everyone who descends to Kampung Naga is the same number of stairs that are the same.

Kampung Naga is located between the hills in the Salawu area which is in the form of a valley, so it is far from the hustle and bustle of the regional traffic of the southern route of Garut-Tasikmalaya. Kampung Naga is a traditional village that is still sustainable, they still hold the traditions of their ancestors. They reject intervention from outsiders if it interferes and damages the sustainability of the village. However, the origin of this village itself does not have a bright spot. There is no clarity of history, when and who was the founder and what lies behind the formation of a village with a culture that is still strong in this tradition.
The name Kampung Naga seems to remind us of an animal name, which is a kind of river that snakes like a dragon when viewed from above. While among the Chinese community, dragons are called liong, which is now often witnessed at the Cap Go Meh event, a Chinese ritual after celebrating Chinese New Year. In Hindu mythology, the dragon snake is used as a symbol that can bring rain and drought. Kampung Naga became the object of Anthropological studies on the life of the Sundanese rural people during the transition from Hindu influence to the influence of Islam in West Java.

Kampung Naga is a traditional village which is specifically a place to live in Naga communities. They save both cultural and natural wealth and the problem. The area of Kampung Naga is approximately $1.5 \mathrm{Ha}$, the majority of Neglasari villagers live as farmers with a narrow ownership area, and smallholders. As a distinctive feature is the craft of bamboo, woven and rattan, whose marketing has reached outside the area and the city, even many visitors to foreigners who buy the handicrafts, when they visit the location of Kampung Naga. This area is a tourist attraction for domestic and foreign tourists.

The highest leader here is known as Kuncen, who acts as a customary leader and caretaker of citizens who are handed down from generation to generation. One of the attractions of Kampung Naga is 
the shape of the house building with a palm fiber roof which can last up to 30 years, and its location facing each other should not be back to the front of the other house is a form of group village patterns. The number of buildings is only 111 units with a total population of 307 people. Another attraction, they still believe in things that are Taboo or Abstinence / Prohibition against the day and during the Pilgrimage Ceremony. The ceremonies that are always carried out by the people of Kampung Naga are : Nyepi Ceremony, Hajat Sasih Ceremony and Marriage Ceremony.

The Kampung Naga community is a community that holds the traditional tradition of karuhun, preserving its cultural traditions, with a very simple color of life's cultural patterns even though the conditions outside this village have followed the lifestyle and culture that is all-advanced or modern. However, they remain obedient to the norms, sociocultural values which are the result of decisions of adat and religious deliberations. For example they still carry out ritual ceremonies, such as pilgrimage ceremonies, problems with Tabu or Larangan or Pamali (in Sundanese).

Kampung Naga is a village whose inhabitants or people use Sundanese, which is often referred to as Urang Sunda. According to Harsojo in Koentjaraningrat, that anthropologically: Sundanese tribes are people who have traditionally used the mother tongue of Sundanese, as well as their dialects in everyday life, and come from and reside in the area of West Java, an area that is also often called Tanah Pasundan or Tatar Sunda (2004). Pure and refined Sundanese language is in the Priangan area, such as in the Districts of Ciamis, Tasikmalaya, Garut, Bandung, Sumedang, Sukabumi and Cianjur. With regard to the research of the Kampung Naga community located between Garut and Tasikmalaya, it is certainly undeniable that the Sundanese Priangan language has been culturally influenced by Islamic Mataram. Almost 90\% of the Kampung Naga community lives outside this village, meaning that only $10 \%$ live inside. Those who live outside the village, are the relatives and descendants of the Kampung Naga community to migrate and participate in the civilization of the outside world, while those who still live in this village, are those who decide to live faithfully to maintain and preserve the customs and traditions that contain values. values and cultural norms.

The word culture has been defined by many anthropologists, but this definition still refers to components such as: values, habits adopted by society, for example language, rules, tools and technology to make the things we use, what we use and eat, organizations followed and institutions in a community (Esther. K. 2006).

Values and norms can be described as follows: Value in a culture is a general opinion about something that is good, fair, polite and others. In
Indonesia, for example, people believe that mutual cooperation, so that it is slow to survive, live in harmony, help each other, togetherness, humility, succumbing, accepting and others are values that are upheld. Meanwhile, individualists, who want to win themselves, indulge in lust, pride and others are values that are considered not good. As with the norm, it usually consists of rules that apply to a particular culture, for example traditionally women should stay at home and men work for a living. If violated by the norm, it is considered to have violated the rules of tradition (Esther. K. 2006).

In the midst of the swift current of globalization the response of the community, in terms of controlling behavior or lampah, can be contrary to the values of their traditional beliefs, namely by giving the rules of conduct or the past regulations which are disclosed as follows: Tata lampah hiji pancen tea take care of overtime, get along with the lines of the line. I want to work on my country, I will be determined, said, lampah, my friend, my friend. That is, is that the rules of conduct are an obligation of every human being who has been given reason to take care of his area, get along with you while remaining in his teachings. Can manage the city and process the nation on the basis of intentions, words, practices that are in line with the provisions (PSSAD Bakosurtanal. 2006).

Based on the many rules in indigenous life and the cultural traditions of the Kampung Naga community, it causes them to try to remain obedient to all the afterlife of the world by carrying out local cultural values and norms, such as in all behavior, traditional ceremonies, teachings lessons from his ancestors and others. Therefore, the people of Kampung Naga are obliged to maintain and preserve their customs which are reflected both in their daily behavior and in ritual ceremonies which are always held regularly. It is as if with this ritual activity, such as the existence of cultural conservation that can be interpreted as follows: Conservation is a process to extend the life of historic cultural heritage, by maintaining, protecting authenticity and its meaning from damage to damage that can be used in the present and the future (Pikiran Rakyat. 2005). It turns out that this conservation is not only in the form of material culture, such as office buildings, shops, mosques, etc., but in non-material culture can be used. It appears in human efforts to maintain, protect and preserve culture, such as ritual ceremonies with various customs that apply to the people of Kampung Naga.

\section{RESEARCH METHODS}

Qualitative, Descriptive and Interview Methods are taken to get data from informants and various respondents. All the elements that we got, recorded, observed and evaluated. The method of research with a qualitative approach, is research with the method of collecting as much as possible the facts 
in detail and in depth about something or a social phenomenon in order to gain understanding or information about the symptoms that we will examine. Therefore, we try to get primary data in the field by recording all the results of interviews through informants, such as from local customary leaders, kuncen and download, while secondary data through several respondents which are estimated to consist of citizens who are considered competent in providing information about the ins and outs customs in the Kampung Naga community where the sample will be taken from $15 \%$ of the total population of 307 people, to around 20 people. This number represents representatives of all members of society here, like elders, people who know the history of Kampung Naga and others.

In Descriptive Research, besides obtaining data from books, magazines and articles known as Library Research or Library Research, we also conducted Field Research or Field Research, which directly came to Kampung Naga to conduct interviews as our research area, to obtain information and data from the predetermined respondent. With open interviews, it is expected that the data and information we obtain will be more accurate, because they not only answer yes or no, but can provide various reasons which are stated. From all the data collected, it is only processed or evaluated, then described in a report with the form of the story.

\section{RESULTS AND DISCUSSION}

\section{History of Kampung Naga}

According to Mr. Risman as an elder in this village, that Kampung Naga had existed since the Neolithicum era, namely the young stone age, and this statement was supported by Indonesian history experts Prof. DR. Uka Tjandrasasmita. According to him, until now no one has been able to provide certainty about who, where and why this community is called Kampung Naga, because in 1956 heirlooms and historical books of their relics were looted and burned by the DI / TII mob under the leadership Karto Suwiryo, caused this community to feel that they lost track of the Sundanese language pareumeun obor. In addition to the above reasons, local adat leaders are still very closed to provide information or explanation about the origin of Kampung Naga.

However, based on historical sources, Kampung Naga came from the legacy of the Galunggung Kingdom. In 739 the Galunggung Kingdom was under the leadership of the Batari Hyang descendants and heirs of Resiguru Sampakwaja who had defended his kingdom, after the collapse of the Galuh Kingdom and the Padjadjaran Kingdom. Beginning of the 18th century the remaining Galunggung Kingdom still existed as Galunggung District centered in Singaparna area, namely the name of Rajadipuntang's youngest son (Permana. 1984). For historical reasons, the taboo Kampong community name Singaparna, because around the 15th and 16th centuries, a valley in Kampung Naga was believed to be a hiding place for Singaparna which guarded the royal heritage from the target of rebels, so that he inherited the knowledge of simplicity from his father, so his son was named Singaparna. Finally, Singaparna was nicknamed the Singaporean Congregation, who built a settlement in the place as a hiding place so that he could continue his life until now, known as Kampung Naga or Nyumput Buni in Nu Caang (Hiding in a Bright Place).

\section{Ritual Ceremonies Performed by the Kampung Naga Community.}

In everyday life, the people of Kampung Naga still hold their karuhun customs, because of the influence and role of kuncen or kokolot as the hands of local leaders. In one year the people of Kampung Naga carry out six routine ceremonies which fall on the month of Muharam, Maulud, Jumadil Akhir, Reuwah (Syaban), Syawal (Ramadhan), and Rayagung. These six activities are also referred to as the Hajat Sasih ceremony, which is a ritual ceremony whose implementation agenda is held on a regular basis. Until now, the Kampung Naga community still continues to preserve various traditional traditions that have taken place, without being affected by the flow of globalization.

a. Pilgrimage Ceremony

b. Mauludan ceremony

c. Ceremony in Late Friday

d. Ngareuwahkeun ceremony

e. Ceremony in Shawwal (Ramadan)

f. Ceremony on Rayagung

\section{Settlement Pattern}

The building of the house is staged with a palm-coated roof, giving birth to contrasting colors between the lush leaves of the trees that shade the village, and makes the building architecture characteristic of the Kampung Naga community. A house in their view must be seen as a ritual categorization arranged according to the gender category in the family. The role of men is in the front room, while the role of women in charge of regulating family household activities dominates other spaces, namely the kitchen. Each house has a separate, the front room that filters the possibility of bad influences that will enter the household, so that it can affect family harmony. Therefore, to prevent it in the upper part of the entrance is hung a kind of bamboo woven called wind tang or repellent. The main door leads to the kitchen room and the second door goes to the living room, and some goah or bedroom are also called pangkeng. Then the middle room called the middle of imah serves as a gathering place for family members, where learning is often used even for the beds of children or relatives who stay overnight. 


\section{Typical Art of the Kampung Naga Community.}

The art which is considered as the ancestral heritage of Kampung Naga at this time can be counted on the fingers, because those who are able to play it are elderly people. The types of traditional traditional arts of this community include: Terbang Gembrung; Angklung; Beluk.

The three elements above need to be preserved so that the customs of the Kampung Naga community still exist, and have a unique identity without being able to be influenced by the outside environment even though this area is one of the domestic and foreign tourist objects, such as from Europe, America, Australia, Japan and other countries. It seems that their presence is quite influential in improving the socio-economic welfare of the Kampung Naga community.

\section{CONCLUSION}

The Kampung Naga community located in the area of Neglasari Village, Salawu District, Tasikmalaya Regency can be accessed by vehicle via the highway between Garut and Tasikmalaya. Internally, the people of Kampung Naga are still able to maintain and preserve their karuhun customs that apply to their citizens. The elders and kuncen of Kampung Naga stated that the people remained obedient to the rules of their ancestors or their ancestors, such as in carrying out various ceremonial activities with applicable conditions. The Kampung Naga community is an indigenous community that is full of local traditions that can be applied to daily life through various traditional ceremonies which are held six times a year, and are known as the Ritual Hajat Sasih Ceremony. At that time the atmosphere of Kampung Naga was different from ordinary days, it seemed residents were more busy preparing traditional ceremonial equipment. They work collaboratively, and as an expression of gratitude to their ancestors, they also offer prayers for the safety and welfare of all members of the Kampung Naga community to realize peace. In addition, they appear in their social, economic and cultural life to try to maintain their karuhun customs so that their independence and attitudes are not affected by current modernization and globalization. Externally, the Kampung Naga community has become a tourist attraction in the West Java area and is visited by many domestic and foreign tourists, as a tourism area.

\section{REFERENCES}

Adimihardja, Kusnaka. 1994. Makalah Pembentukan Pelopor dan Kebiasaan Merantau dalam Perpekrif Budaya dan Falsafah Sunda Bandung.

Akademi Teknik YKPN, 1988. Laporan Kuliah Kerja Kampung Naga. Jogyakarta. Jurusan Teknik Arsitektur.
Havland, William A. Soekadidjo. 1988. Antropologi. Edisi keempat. Jilid I. Erlangga Jakarta.

Koentjaraningrat. 2004. Kebudayaan Sunda dalam Manusia dan Kebudayaan di Indonesia. Jakarta : Djambatan.

Permana, T. 1984. Rintisan Penelusuran Masa Silam: Sejarah Jawa Barat. Kerta Mukti Gapuraning Rahayu.

Pusat Survei Sumberdaya Alam Darat. 2006. Geografi Indonesia Pangandaran Tangkuban Perahu. Bakosurtanal.

Suganda, Her. 2006 Kampung Naga Mempertahankan Tradisi. Bandung : PT. Kiblat Buku Utama.

Suhandi, Agraha. 2014. Pola Hidup Masyarakat Indonesia Bandung. Fakultas Sastra Universitas Padjadjaran.

Suryadi, 1974. Masyarakat Sunda Budaya dan Problem Alumni Bandung.

Warnaen, Suwarsih. 1988. Analisis Kebudayaan. Jakarta. 